\title{
V.-ANATOMICAL STUDIES ON THE BRAINS OF CIRIMINALS.
}

Anatomische Studien an Verbrecher-Gehinnen, fur Anthropologen, Mediciner, Juristen und Psychologen Bhanbeitet. Von Moriz Belledikt. Mit 12 T'afoln und 8 Holzschnitten. Wien, 1879. Wilhelm Branmuller, K. K. llof, und Universitat Buchinandler. (Anutomical studies of criminals' brains for anthropological, medicul, judicial and psychological research and purposes. By Moriz Benedikt. With 12 ellgravings and 8 woodcuts.)

This work is dedicated to a number of physicians and others, mainly Hungarian and Croatian. Assistance is acknowledged from many persons, such as ministers of justice and prison inspectore, for material furnished. This is noticeable as indicative of inter-Carpathian Adriatic progress against superstitious prejudice, which hitherto has withheld such material fiom stadelits.

The introduction may be condensed as follows: That there is a correspondence in anatomical plan and physiological derelopment of the brains of men as well as in their thoughts, feelings, volition and capabilities, is a discovery as old as Erasistratus, who first gave it utterance, at a time, too, when but crude judgments could consider it. 'The indifferent progress of exact kuowledgo of brain structure and functions was due to the want of auy wide-spread recognition of these analogies, a belief in which was latent for more than 100 years among the learncd classes before their demonstration.

'The plitosophies of Blumenbach and Gall appeared with the general advance of science. 'They paved the way to more accurate knowledge, and their stores of thought were not enough appreciated. A new impulse was then given to auatomical brain studies, which previously had received very little attention. Although Gall's incitements to studies in this new field were great and successful, so many were the mistakes in details that he made, that opposition hailed these as evidences of the entire falsity of bis doctrine, and antitheses were as nunerous as the works of adherents. Since then the literati of all lands have forwarded our knowledge of the skull and brain. Notwithstanding the direct psychological tendencies of these revelations, there has been no other than argumentative persecution raised against the study of the subject.

In France, Leuret, Gratiolet and Broca, in Germany, Huschke, Virchow and Bischoff, in England, $O$ wen, Huxley and their schools, and in Italy, Lombroso, are recalled to nind as most prominent in these researches and most useful to the author in his present work. 
instmiment with which to senrch for the location of faults, for the starting point of abnormalities cannot be found by unassisted ocular inspection.

3. Befure any psychic connection can be traced to peculiarities of brain strincture, very much more than a mere outline of the supposed character of the individual must accompany the investigator's record. Heredity, disease, accidents, associations, incentives and, what is seldom if ever known, the inner life of the man, have their share of influence.

The lonie record of which benedikt speaks as pertaining to each case, so far from having no significance miglit become the most valuable part, if it nnly went fitr enough, $i . e_{\text {, }}$ microscopically. Had we screral thousand such bale records made by conscientions, able students, we might possibly begin to tabulate the most astonnding results.

Notwithstanding the negative outcome of such work thns far, as the author ways, "it will live" and help to guide other research es, and however laby rinthine an anatomico-psychological study may appear to he, when we comprare it with other sciences and the advances they liave madc toward perfection against opposition of the fiercest kind, we may take enconragement, and snch niemoirs as the one before us are at least snggestive, even though they do not add to our stores of positive knowledge.

s. v. C.

\section{SHORTER NOTICES.}

I. Atlas of Skin Diskases. By Louis A. Duhring, M. D. Part VI. Plilislelphia, 1879. J. B. Lippincott \& Co. Chicago, Jauscn, Mcclurg \& Co.

II. A Clinical Trratisf on tue Diseases of tue Nervoug Systej. By M. Rosentlial. (With a prefice by Prof. ('harcot.) 'I'ranslated from the author's revised and enlarged editiou, by J. Putzel, MI. D. New York, Wm. Wood \& Co., $1879 ; 555$ pages. Chicago, Jansen, McClurg \& Co.

III. Lectures on Electricity in its Rhlations to Medicine And Surgery. liy A. 1). Rockwell, A. M., M. D. New York, IVm. Wool \& Co., 1879. Clicago, IV. T.Keener.

IV. First Linfs in Tuerapectics, as Based on the Modes ant the Proces:es of Healing, as Ocrurring Spontancously in Disease, and on the Mockes and Proce'sses of Dying, as resulting naturally from diserse. In a series of lecturcs. By Alex. Harvey, M. A., M. D. (Ellin.) New York, 1870, D. Appleton \& Co. Clicago, Jansen, McClurg \& Co. 